\title{
DTL-Eco System by Digital Storytelling to Develop Knowledge and Digital Intelligence for Teacher Profession Students
}

\author{
Kritsupath Sarnok, Panita Wannapiroon, and Prachyanun Nilsook
}

\begin{abstract}
The objective of this research aims 1) to study the components of the digital learning ecosystem 2) to design the digital learning ecosystem with digital story telling for students in the teaching profession 3) to assess the efficiency and suitability of the system. The research tools are the efficiency and appropriateness assessment form of DTL-Eco System. Data were analysed by means and standard deviation. The research findings 1) The DTL-Eco System consists of 2 components: (1) living beings such as learners and the instructor. (2) none-living beings such as equipment used to support learning and teaching and learning and teaching management, 2) DTL-Eco System performance evaluation part 1 , system overall performance evaluation are at the most suitable level $(\overline{\mathrm{x}}=4.68, S D=0.42)$, part 2 efficiency evaluation results of the DTL-Eco System are divided into 4 parts. From the evaluation of all 30 questions, the evaluation results of using digital tools in searching and information processes are. at the highest level $(\bar{x}=4.93, S D=$ 0.28), part 3 suitability evaluation of the DTL-Eco System, which is divided into 3 major topics, the most appropriate result is the DTL-Eco System developed for development. Emotional intelligence in the digital world and the development of skills in using tools and digital media are possible to try out $(\overline{\mathbf{X}}=4.85$, $S D=0.38$ ).
\end{abstract}

Index Terms-DTL-eco system, digital storytelling, digital intelligence, teacher profession students.

\section{INTRODUCTION}

Nowadays, the advancement of technology affects life and learning styles through various medias in people of all ages including children in school [1]. As a result of this rapid changes, schools and institutions, including instructors must develop themselves in order to step into a new learning world Acceptance and adjustment of thought processes, changing teaching and learning methods, techniques and teaching media as well as changing attitudes. The learners' perceptions and behaviours have caused instructors and administrators to adjust their thinking and find new teaching methods, applying new technology to be used as media or tools to create and stimulate learning to suit for new generations of learners [2].

Therefore, learning management in the rapidly changing new century of technology is a very challenging and important issue for instructors and educational institutions. The design of teaching activities and the creation of a new

Manuscript received June 15, 2020; revised October 21, 2020.

Kritsupath Sarnok is with the Vongchavalitkul University, Thailand (e-mail: kritsupath_Sar@vu.ac.th).

Panita Wannapiroon and Prachyanun Nilsook are with the King Mongkut's University of Technology North Bangkok, Thailand. learning society are therefore not only focused on educating the students by instructors but also the design of teaching activities and the creation of a learning environment system that focuses on giving students the opportunity to learn and do activities at all times through various existing digital technology and tools [3]. By using the model of teaching and learning to organize the digital environment which is based on the arrangement of "Digital Learning Ecosystem" or digital learning system. The system has variety of components, including the use of information and communication technology (ICT) and the use of e-learning systems, which have the basic structure of the use of internet for learning [4]. This type of teaching and learning is called the Digital Teaching and Learning Ecosystem (DTLE). The system is the relationship between various things in an ecosystem consisting of living things (Biotic) and non-living things (Abiotic) including all the physical components that the environment interacts with, such as devices, tools or hardware, operating systems, and applications or software and network [5]. These can be used with the learners or as a group of content creators. It is linked to a learning community within the digital ecosystem [6] in the form of diversity, that being used to search for learning on a daily basis in both instructor groups and learn groups within that digital ecosystem. This is because every part of everyone's life now has another existence in the digital world. There is an interest and desire in using various technologies all the time [7]. For example, in the field of education, such as when the student has been assigned by the instructor they will use the tools and skills of their digital native to think, analyse and search for information in the digital ecosystem and then design and produce the presentation in the form of storytelling through Digital media (Digital Storytelling), which is one of the activities that modern learners do as a routine in the world of social media. The medias used in digital storytelling is storytelling through media and digital technology to convey the story and emotions of the storyteller. This digital storytelling is a medium that covers many types of media such as images, movies, animation, audio, video, games, content designed for websites and mobile applications, etc. All of this, when using digital technology to compile media into stories, it will be suitable for students who need to learn to create intelligence and awareness within themselves. Therefore, when using this method to adjust teaching and learning in the digital ecosystem, the result is considered a good method. Because digital storytelling is focused on creating media to encourage learners to be interested and motivated, allowing learners 
more concentrate. Because the content is tied into a story to make it easier to understand than it is just normal information that is broadcasted in a normal classroom.

From the above significance, Nowadays learning and sharing of information, knowledge, and news are widespread in the digital ecosystem. The researcher is interested to study, design and develop DTL-Eco System Learning Management by using digital storytelling as a tool for developing digital knowledge and intelligence of instructor profession students in order to build immunity for students as well as build online living skills as well as create digital intelligence before graduating to become instructors and educational personnel. The necessary knowledge skills are the subject of instructor skills and knowledge in the teaching profession. Including digital intelligence skills, including skills in using tools and digital media, emotional intelligence in the digital world such as understanding, empathy, generous to others on the digital world, awareness and the ability to control emotions in the real world and emotions that can be demonstrated in the digital world.

\section{RESEARCH OBJECTIVE}

1) To design a digital learning ecosystem by using digital storytelling learning process for teacher profession students.

2) To study the process of teaching and learning by digital storytelling in the digital learning ecosystem for teacher profession students.

3) To evaluate the appropriateness of digital learning ecosystem and digital storytelling learning process for teacher profession students.

In the DTL-Eco System by Digital Storytelling to Develop

Knowledge and Digital Intelligence for Teacher Profession Students, the conceptual framework is shown in Fig. 1

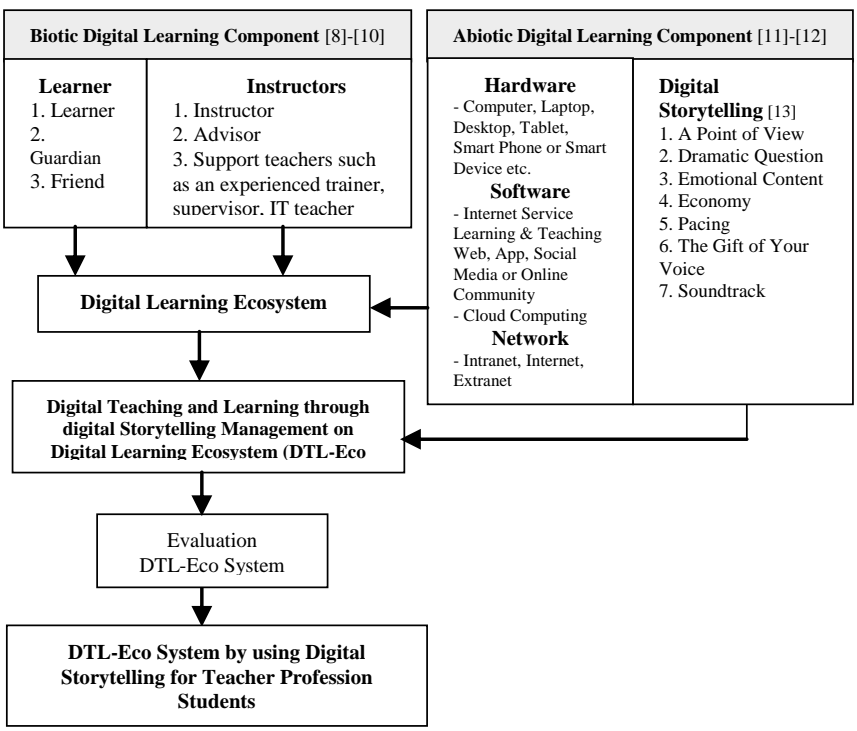

Fig. 1. Conceptual framework.

\section{SCOPE OF RESEARCH}

1) The population were 12 educational experts, who are experts in teaching and learning design and information technology and communication for education.

2) The samples were 6 instructional design experts and 6 ICT for education experts with at least 5-year experience in the fields. They were selected using purposive sampling techniques.

\section{RESEARCH METHODS}

The researcher has designed and developed the DTL-Eco System for teaching and learning of instructors. Which the operation procedures are as follows:

1) The researcher studied documents and research related to digital ecosystem, digital storytelling, and instructor professional students in order to see patterns, characteristics, and previous research results.

2) The researcher studied the document and DTL-Eco System Development Program to use in the development of the digital storytelling system in the DTL-Eco System.

3) The researcher conducted front-end analysis in three parts: 1) Context analysis including needs analysis, curriculum analysis and module analysis, 2) Learner analysis including new generations' lifestyle, needs for education, accessibility to content knowledge and the critical thinking for student and 3) Learning task analysis.

4) The researcher designed Digital Learning Ecosystem through using Digital Storytelling for instructor profession students follow the design steps of AAA Model [14] as follows:

- Part 1: Instructor, Learner \& Digital Learning Environment.

- Part 2: Digital Storytelling.

- Part 3: Authentic Assessment Learning in Digital Learning Ecosystem.

5) The researcher developed the DTL-Eco System which can be divided into 3 parts which are 1 instructor, 2 learner, and 3 learning environments by the system administrator.

6) Initial assessment of DTL-Eco System developed by research consultants in order to use the information for improvement.

7) The researcher created the tool as an evaluation tool to evaluate the efficiency and suitability of the developed DTL-Eco System.

8) The researcher used the suitability assessment form created for the 5 experts to assess the consistency of the questions, analyse the consistency index (IOC) by selecting the question that has the value between 0.50-1.00 before using it.

9) The researcher proposed the developed DTL-Eco System to the experts to assess the suitability and the conclusion of the system evaluation.

\section{RESUlTS}

1) DTL-Eco System consists of 2 components which are 1) living thing (Biotic), and 2) non-living things (Abiotic) as presented in Fig. 2

From the figure 2, Summarization of the analysis and synthesis of the components of digital storytelling in the 
digital learning ecosystem by dividing the components into 2 main component namely Biotic component and Abiotic Component. The first component is living thins consists of students and instructors with further details as needed or needs of the learning ecosystem. The second component is non-living things consist of 1) tools, devices 2) programs or applications, 3) networking, and 4) principles and theories for teaching and learning [15].

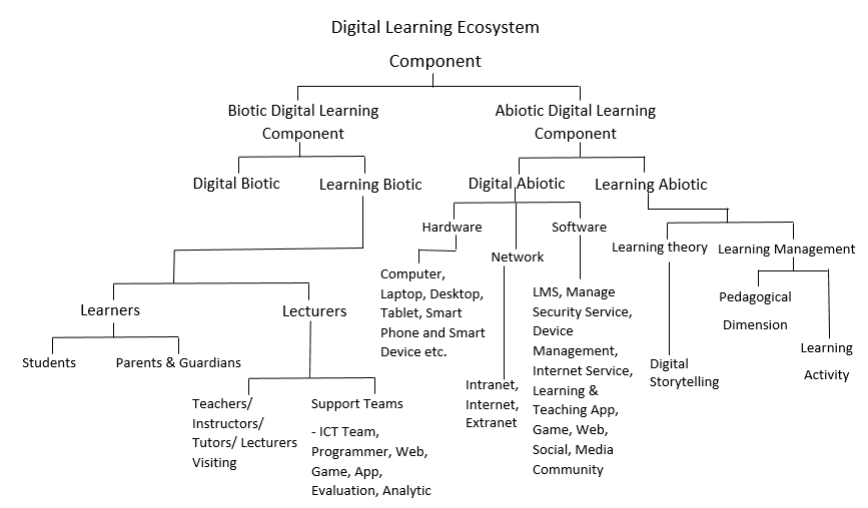

Fig. 2. Analysis and synthesis of DTL-Eco System components [15].

2) The design and development of the DTL-Eco System consists of 3 components namely students, instructors, network administrators as details as follows:

a) Learners

Program modules in the DTL-eco System in the students section consists of 7 subprogram modules namely Calendar, Activity, Course, Learning, Works, Discussion and Message as detail as follows:

- Calendar is a module for planning and checking personal schedule and activities of members in the digital ecosystem.

- Activity is a module of digital storytelling activities for learners or members of the system, with the objective of being used as activities to create own digital storytelling In the process of producing digital storytelling media students will learn the principles and methods of developing digital media and the content they want to convey to the public. The digital storytelling activities have 7 steps as follows: 1) Setting the point of view of the presentation 2) Creating open narrative issues 3) Creating the mood of the story 4) Sound effects 5) Techniques for using pictures and sound in the story. 6) Consideration of the value and worth of the story.

- Course is a module showing course details, courses and course descriptions that students must know in each course they want to learn.

- Learning is a module of learning in the content of that course consists of taking the test before studying, learning content, activity in the content, and taking the test after studying.

- Works is a module for assigning work that is in the form of digital storytelling for students which is the result of learning in number 4 and integrating it as an activity in number 2 and then creating a digital story to share in the DTL-Eco System.

- Discussion is a module for exchanging knowledge about various issues arising from learning, activities and study visits of others. These are commented from members in the system such as from friends, instructors or parents who want to learn in the system too.

- Message is a module for depositing or sending messages in order to exchange inquiries or request information from each other in the system.

When the learners login the system the main screen feature shows as Fig. 3

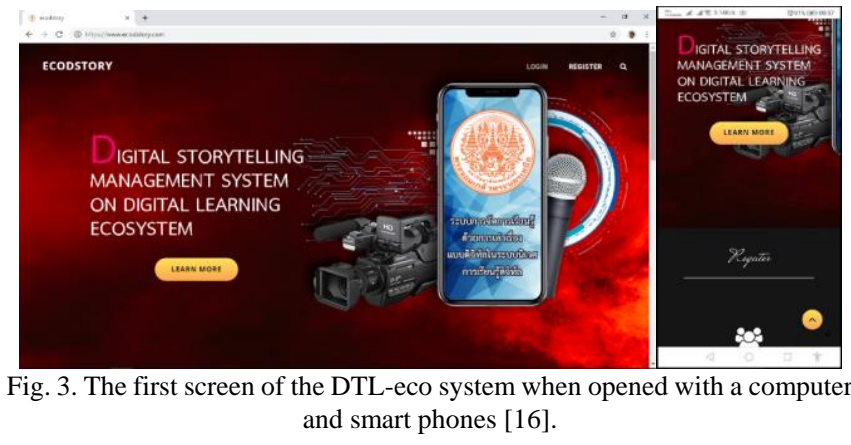

Instructors section is a display section which is responsible for managing learning activities and teaching and learning with digital storytelling in the DTL-eco System, in which instructors can provide various advice on learning and activities including interaction with students as follows:

Creating content in the system

In the menu for education content or Learning is the part that instructors have put in professional content and learning activities. In this section, there are 5 lessons, each lesson consists of pre-test, activity, and post-test.

- Chapter 1: Basic knowledge about teacher profession

- Chapter 2: Teacher Professional Standards as prescribed by the Teacher Council of Thailand

- Chapter 3: Knowledge standards and teacher professional experience standards

- Chapter 4 Performance standards

- Chapter 5: Standards of conduct and behavioural patterns according to professional ethics

Test

As for the evaluation, the instructor will prepare the evaluation form in 2 ways which is the first one is the evaluation before studying. The pre-test quiz menu consist of 95 questions, covers all lesson content. After the learners know their pre-test results, then study the content and do the post test. After that the system will show the result of each student's as in the Fig. 4

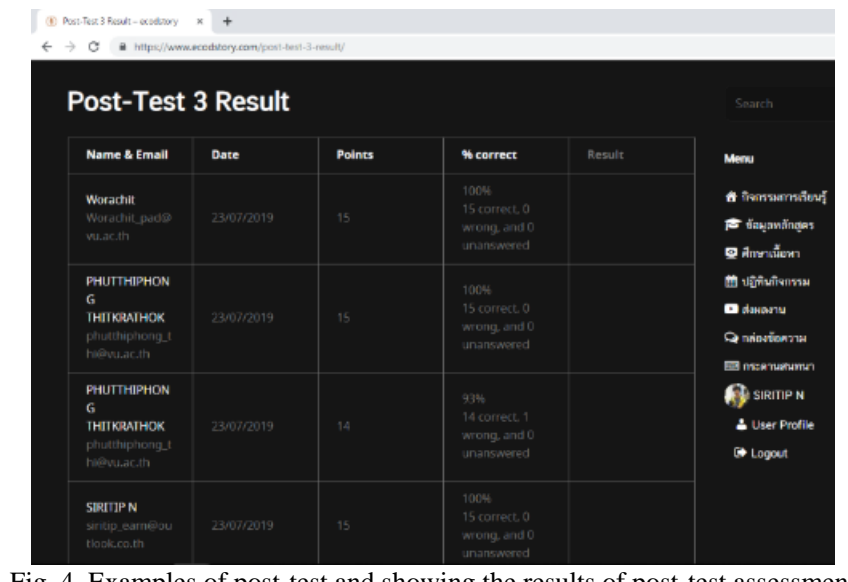

Fig. 4. Examples of post-test and showing the results of post-test assessment for each student [16]. 


\section{Appointment Calendar}

Appointments calendar is a part of scheduling activities for instructors to inform students or other members such as appointments, assignments, exams, homework, meetings, special activities, etc.

b) System Administrator Section

In the case of the system administrator is the main instructor, the administrator has right to edit the information and format of the program. If the system administrator is not the main instructors, the administrator has no right to edit content or to interact with students or members of the DTL-eco System. Both of these rights must be logged in to the system as well. Sample of modifying and manipulating data as shown in Fig. 5

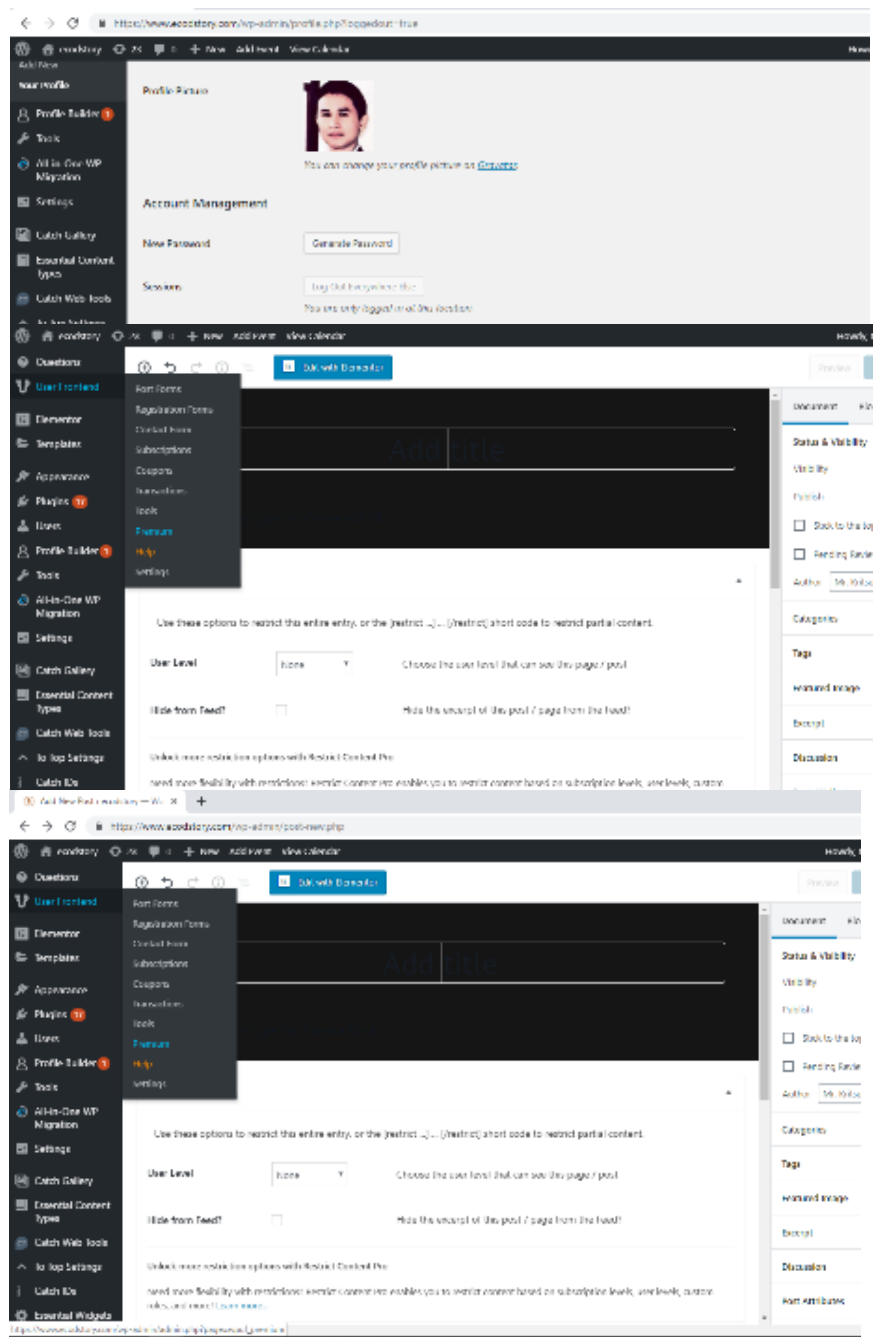

Fig. 5. Examples of modifying and managing information of the system administrators [16].

3) DTL-Eco System Overall Performance and Suitability Assessment Results. And the system individual aspect evaluation result as in the Table I and II.

From Table I, the overall performance evaluation of the DTL-Eco System has the most suitable evaluation result $(\overline{\mathrm{X}}=$ $4.68, S D=0.42)$. When examine individual aspect, it is found that the Learning and teaching procedure is most appropriate ( $\bar{x}=4.85, S D=0.37$ ) and the second is the learning and teaching activities and procedure covered the main components of the instructional model $(\bar{X}=4.71, S D=0.25)$. The least evaluation was learning and teaching preparation of the preparation $(\bar{X}=4.61, S D=0.52)$ which has the highest rating as well.

TABLE I: DTL-ECO SYSTEM OVERALL PERFORMANCE EVALUATION RESULTS [16]

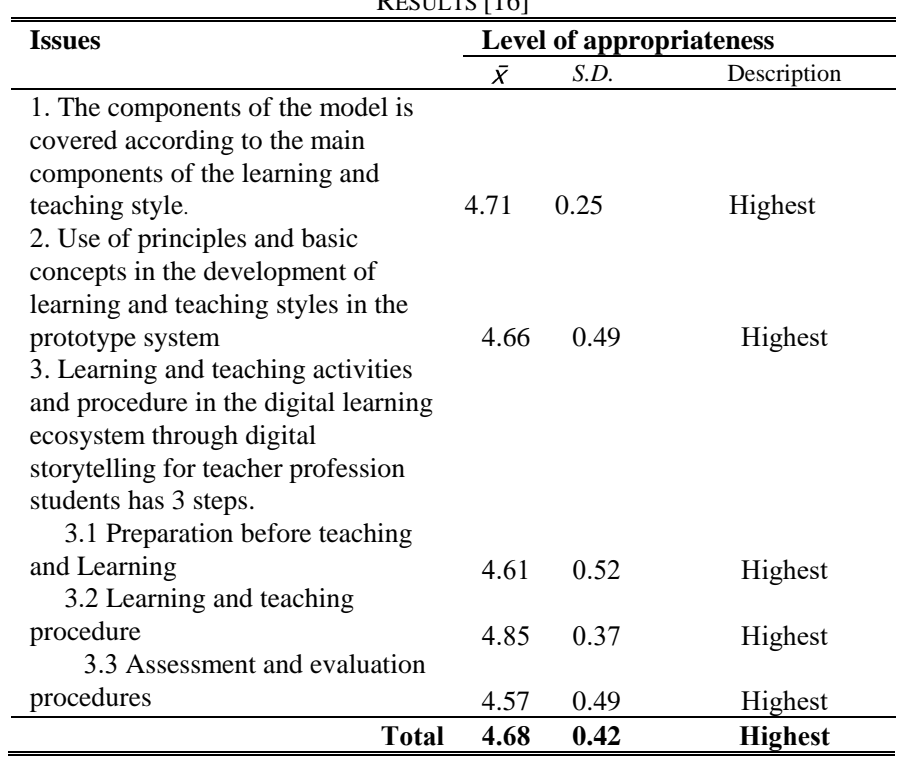

TABLE II: DTL-ECO SYSTEM SYSTEM PERFORMANCE EVALUATION RESULTS [16]

\begin{tabular}{|c|c|c|c|}
\hline \multirow[t]{2}{*}{ Issues } & \multicolumn{3}{|c|}{ Level of appropriateness } \\
\hline & $\bar{X}$ & S.D. & Description \\
\hline \multicolumn{4}{|l|}{ 1. Input Factors } \\
\hline 1.1 Digital Learning Ecosystem & 4.92 & 0.28 & Highest \\
\hline 1.2 Objectives of the instructional & & & \\
\hline model & 4.92 & 0.28 & Highest \\
\hline 1.3 Roles of learners & 4.92 & 0.28 & Highest \\
\hline 1.4 Roles of instructors & 4.85 & 0.38 & Highest \\
\hline \multicolumn{4}{|l|}{ Total evaluation results of the } \\
\hline \multicolumn{4}{|l|}{$\begin{array}{l}\text { 2. Teaching and learning process } \\
\text { through digital storytelling }\end{array}$} \\
\hline \multicolumn{4}{|l|}{ 2.1 Preparation before teaching } \\
\hline \multicolumn{4}{|l|}{ and learning } \\
\hline 1. Student orientation & 4.85 & 0.38 & Highest \\
\hline 2. Registration and practice & 4.77 & 0.44 & Highest \\
\hline 3. Learners management & 4.69 & 0.48 & Highest \\
\hline 4. Measuring skills in using & & & \\
\hline tools and digital media & 4.92 & 0.28 & Highest \\
\hline
\end{tabular}

2.2 Teaching and Learning

Procedures

1. Introduction and

understanding of lessons and

methods of teaching and learning

with digital storytelling.

2. Teaching Step 1:

Determining the viewpoint of story presentation

3. Teaching Step 2 Creating an Opening Issue

4. Teaching Step 3 Creating the emotions of the story

5. Teaching Step 4 Using sound effects in stories

6. Teaching step 5 techniques for using images and sounds

7. Teaching Step 6 Creating value

8. Teaching Step 7 Using

digital storytelling materials for learning in the DTL-Eco System.

9. Summary of learning outcomes through digital storytelling in the DTL-Eco System

2.3 Assessment and Evaluation Procedures

$\begin{array}{lll}4.85 & 0.38 & \text { Highest } \\ 4.85 & 0.38 & \text { Highest } \\ 4.85 & 0.38 & \text { Highest } \\ 4.85 & 0.38 & \text { Highest } \\ 4.92 & 0.28 & \text { Highest } \\ 4.85 & 0.38 & \text { Highest } \\ 4.77 & 0.44 & \text { Highest } \\ 4.92 & 0.28 & \text { Highest } \\ 4.92 & 0.28 & \text { Highest } \\ & & \end{array}$




\begin{tabular}{|c|c|c|c|}
\hline $\begin{array}{l}\text { 1. Learning achievement } \\
\text { assessment }\end{array}$ & 460 & 0,48 & \\
\hline 2. Emotional intelligence in & (1.0 & 0.70 & Hignest \\
\hline $\begin{array}{l}\text { the digital world assessment } \\
\text { 3. Skills in using tools and }\end{array}$ & 4.92 & 0.28 & Highest \\
\hline $\begin{array}{l}\text { digital media assessment } \\
\text { 4. Satisfaction with learning in }\end{array}$ & 4.92 & 0.28 & Highest \\
\hline the system assessment & 4.85 & 0.38 & Highest \\
\hline $\begin{array}{l}\text { Total evaluation of the teaching } \\
\text { and learning procedures } \\
\text { 3. Output }\end{array}$ & 4.85 & 0.43 & Highest \\
\hline $\begin{array}{l}\text { 3.1 Digital Emotional Intelligence } \\
\text { 1. Understanding, empathy and } \\
\text { kindness to others in the digital world }\end{array}$ & & & \\
\hline $\begin{array}{l}\text { 2. Digital awareness and } \\
\text { control }\end{array}$ & 4.92 & 0.28 & Highest \\
\hline 3. Digital and social awareness & 4.92 & 0.28 & Highest \\
\hline $\begin{array}{l}\text { 3.2 Digital media tools and skills } \\
\text { 1. The use of digital tools in } \\
\text { searching and information processes }\end{array}$ & 4.92 & 0.28 & Highest \\
\hline $\begin{array}{l}\text { 2. Use of digital tools in the } \\
\text { development of innovations, media, } \\
\text { product, or solutions }\end{array}$ & 4.93 & 0.28 & Highest \\
\hline $\begin{array}{l}\text { 3. Use of digital tools to } \\
\text { promote innovation, media, products, } \\
\text { or solutions to work or professions } \\
\text { 4. Use of digital tools to }\end{array}$ & 4.85 & 0.38 & Highest \\
\hline $\begin{array}{l}\text { stimulate the outcomes or ways of } \\
\text { encouraging further practice in life or } \\
\text { in society }\end{array}$ & 4.77 & 0.60 & Highest \\
\hline $\begin{array}{l}\text { Total evaluation results of the } \\
\text { Outcomes }\end{array}$ & 4.76 & 0.61 & Highest \\
\hline $\begin{array}{l}\text { 4. Feedback } \\
4.1 \text { Opinions towards the } \\
\text { development of learners' skills } \\
\text { 4.2 Comments on instructional }\end{array}$ & 4.87 & 0.49 & Highest \\
\hline management to the instructors & 4.85 & 0.38 & Highest \\
\hline & 4.84 & 0.39 & Highest \\
\hline & 4.84 & 0.38 & Highest \\
\hline $\begin{array}{l}\text { Total evaluation of DTL-Eco } \\
\text { System Components }\end{array}$ & 4.87 & 0.36 & Highest \\
\hline
\end{tabular}

From Table II, the results of the performance evaluation of the DTL-Eco System in individual aspect are divided into 4 aspects as follows:

1) Input Factors: The overall evaluation results of the system are at the most appropriate level $(\bar{x}=4.90, S D=0.30)$. When examine individual aspect, it is found that the digital learning ecosystem, defining the objectives of the instructional model, and defining the role of learners is most appropriate $(\bar{X}=4.92, S D=0.28)$.

2) Learning and teaching procedure (Learning Process) through digital storytelling, the assessment is divided into 3 major topics. 30 sub-topics. The first is the preparation before teaching and learning. The results of the assessment in the first aspect, the item with the highest assessment result and the most appropriate was item 4the measurement of tools and digital media skills $(\bar{x}=$ $4.92, S D=0.28)$. The second is teaching and learning procedures. The evaluation result was at the most appropriate level, which is Step 4 sound effects in the story. Teaching Step 7: Using digital storytelling media for learning in the digital learning ecosystem (DTL-ecoLMS Learning) and summarizing learning results from learning with digital storytelling in the ecosystem. Digital learning (DTL-ecoLMS) $(\bar{x}=4.92$, $S D=0.28)$ and the last aspect, the third is measurement and evaluation. In which the evaluation result is at the highest level, which is the measurement of emotional intelligence in the digital world and the evaluation of the skills in using tools and digital media $(\bar{x}=4.92, S D=$ 0.28). In all 3 aspects of the evaluation, the overall evaluation result is at the most suitable level $(\bar{x}=4.77, S D$ $=0.43$ ).

3) Outputs: The evaluation result was most appropriate level $(\bar{x}=4.81, S D=0.49)$. The assessment is divided into two areas. The first, emotional intelligence in the digital world which all evaluation results were the most appropriate level, namely understanding, sympathy, kindness to others in the digital world, awareness and emotional control in the digital world, and social awareness on the digital world $(\bar{x}=4.92, S D=0.28)$ The second was digital tools and media skills. The most appropriate evaluation results were using of digital tools in searching and information procedures $(\bar{X}=4.92, S D=0.28)$.

4) Feedback received overall evaluation and 2 individual aspects namely the result of opinions towards the development of learners' skills and opinions towards instructors' instructional management were the most appropriate level $(\bar{x}=4.85, S D=0.38)$ respectively. And from the evaluation of the suitability of the DTL-Eco System which is shown in Table III.

TABLE III: DTL-ECO SYSTEM APPROPRIATENESS EVALUATION RESULTS

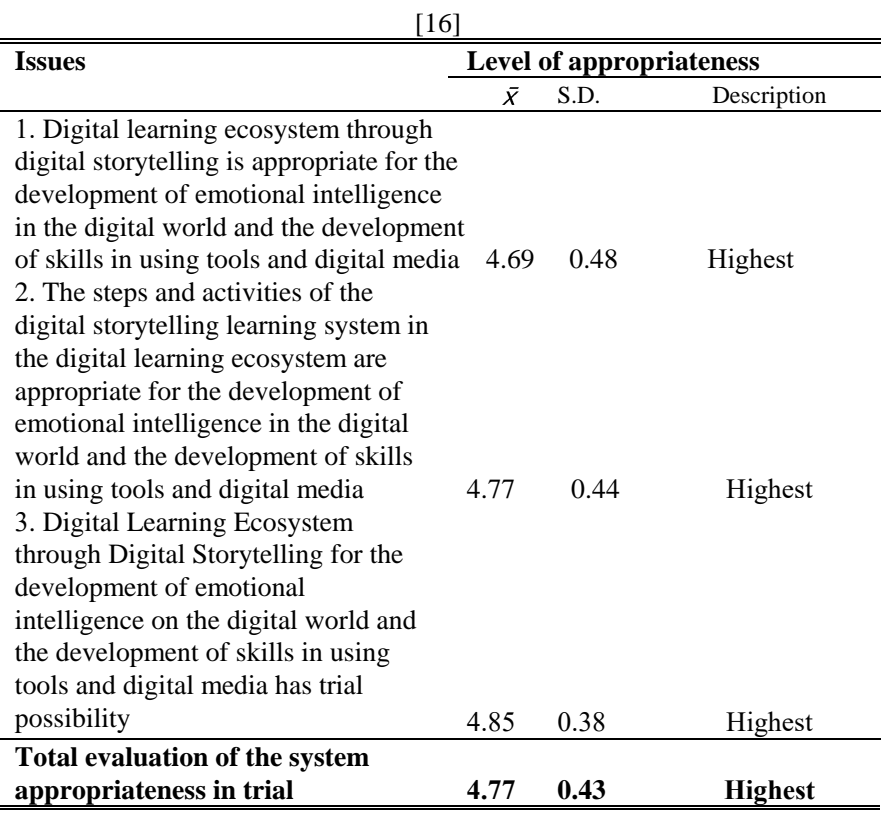

From Table III, when examine the evaluation of the appropriateness of the DTL-Eco System, the most appropriate result was the digital learning ecosystem through digital storytelling for the development of emotional intelligence on the digital world and the development of skills in using tools and digital media has trial possibility $(\bar{X}=$ $4.85, S D=0.38)$. Now at the most appropriate level $(\bar{X}=4.77$, $S D=0.43)$.

\section{Discussion THE RESUlts}

The study of the digital learning ecosystem components to develop the DTL-Eco System for teaching and learning through digital storytelling methods is consistent with Eka 
Jeladze and Kai Pata, who said at the moment the school has adapted due to the rapid changes in technology, schools have to develop digital learning ecosystem. Based on the data from 62 school instructors and ICT managers, it is agreed that for sustainable learning and to reduce learning management costs schools should integrate information technology and organize it in a systematic. We have developed a model of the concept of an intelligent learning ecosystem in the form of a digital system to enable the interaction of all involved persons and resulting in sustainable learning change [17], [18]. The research found that:

1) The components of the Digital Learning Ecosystem consists of living things and non-living things. The living things are learners and instructors. The non-living thing are tools, devices used to support teaching and learning and the method of teaching and learning with digital storytelling. The study consistent with Mart Laanpere, Kai Pata, Peeter Normak, and Hans Põldoja, who say that the digital ecosystem should be designed with environments, tools and equipment that support instructor in teaching, help instructors easily use for online learning [19].

2) The evaluation of the Performance of the DTL-Eco System, Part 1 Evaluation of the System's Overall Performance. The evaluation result was the most appropriate level $(\bar{x}=4.68, S D=0.42)$, when examine individual aspect found that the teaching and learning procedure was the most appropriate $(\bar{x}=4.85, S D=0.37)$ Part 2 DTL-Eco System performance evaluation, The evaluation divided into 4 topics namely inputs, Teaching and learning process through digital storytelling is consistent with Joe Lambert and Kimmo Vänni mentioned about the 7 steps of Digital Storytelling: Step 1. Owning Your Insights, 2. Owning Your Emotions, 3. Finding The Moment, 4. Seeing Your Story, 5. Hearing Your Story, 6. Assembling Your Story, and 7. Sharing Your Story [20], [21]. Learning from content in the form of digital storytelling media learners will use electronic devices to learn from a variety of media, including still images, short films, animation, audio, video, games, applications, or content designed on websites that are in the cloud. This is consistent with Halah Ahmed Alismail mentioned about integrating learning through digital storytelling in $2^{\text {st }}$ century education, he said technology is an important factor in education for new generation. The instructor should use it in teaching management in order to benefit students' learning. By integrating multimedia digital storytelling, using teaching tools including synthesis, analysis, evaluation, presentation, and interaction with the benefit of technology [22].

3 ) Outputs and 4. Feedback. The aspect that has the highest evaluation result was the $1^{\text {st }}$ aspect, input factors $(\bar{X}=4.90$, $S D=0.30$ ) and from the evaluation of all 30 questions, the evaluation results of using digital tools in searching and information processes was highest level $(\bar{x}=4.93$, $S D=0.28)$ and is consistent with Chatchada Akarasriworn Nagaoka and Kritchanat Santawee, which stated that awareness, skills for knowing media and information through online media [23]. Part 3The evaluation of the appropriateness of the DTL-Eco System divided the evaluation into 3 major topics. The most appropriate result was the DTL-Eco System for the development of emotional intelligence in the digital world and the development of skills in using tools and digital media has trial possibility $(\overline{\mathrm{X}}=4.85, \mathrm{SD}=0.38)$. The overall evaluation was most appropriate $(\overline{\mathrm{X}}=4.77$, $\mathrm{SD}=0.43)$.

\section{A. Suggestions}

1) Examining the components of the DTL-Eco System, it is found that the most important input factors are the role of learners in the learning process by using digital storytelling and measuring the skills of using tools and digital media is very important in accordance with [24] presented in an academic article about the benefits of storytelling through digital media that is suitable for teaching and learning. called Technology Pedagogical Content Knowledge (TPCK), which is the learning of content through technology. This method is very suitable for teaching and learning in the 21 st century. In addition, in organizing the digital learning ecosystem through digital storytelling for students, instructors should also consider the components of study and readiness of the use of technology and should consider the field of teacher profession students. Content used in teaching and learning and internal technology support both from the department, faculty and policy of the university itself. This is consistent with Phumeechanya, N., Wannapiroon, P., \& Nilsook, P who said that teaching and learning must be aware of the context of the learners [25].

2) The teaching and learning activities in the DTL-Eco System received overall evaluation in high level When examine individual aspect, it is found that learning through digital storytelling was highest appropriate for the development of emotional intelligence in the digital world and the development of skills in using tools and digital media. This is consistent with Tendero's research states that digital storytelling is becoming popular and is considered a way of storytelling through close and real-life media. Because of the potential power of today's technology caused some instructors to seriously see the benefits from using digital storytelling as an analytical teaching tool for reflecting workers' thoughts. From the results it appears that digital storytelling is a good way to create learning outcomes and to develop their own unique characteristics [26].

3) Suggestions for the development of DTL-Eco System, the experts have suggested as follows:

- The DTL-Eco System should be designed and implemented with consideration to the support of other vocational courses, such as the Diploma of Teaching Profession Or a master's degree program that has already been licensed for a teacher profession.

- In the implementation, the DTL-Eco System should be designed in collaboration with the teacher profession department or being certified by the Teachers Council of Thailand. Learners who have passed and have a high score in accordance with the Teachers Council of Thailand criteria can be compared to obtain a professional teaching license in the future. 
- In actual use, the DTL-Eco System will be used in the future in the case of a cooperative project with the teacher professional authority or after receiving approval from the Teachers Council of Thailand. Should allow administrative instructors, assistant instructors or instructors who do not have a professional certificate to be enrolled and trained to develop themselves to be knowledgeable according to the criteria of the Teachers Council of Thailand and then can be compared to transfer to get a professional teaching license.

\section{CONCLUSION}

The summary of the research can be summarized as follows:

The study of the components and design of the digital learning ecosystem found that the components for design can be divided into 2 components namely 1 ) living beings namely learners and instructors including those involved in teaching management such as tutors, lectures visiting, Support Teams (ICT Team, Programmer, Web, Game, App, Evaluation, Analytic) and learner supporters such as parents or guardians 2) Non-living being consists of tools/ equipment used to support teaching and learning and teaching management as shown in Fig. 2

Assessment of the efficiency and appropriateness of the DTL-Eco System is divided into 3 parts as follows:

Part 1: Assessment of overall system performance. The evaluation result is at the most suitable level $(\bar{x}=4.68, S D=$ 0.42 ), when investigate in individual aspect, it is found that the aspect of the teaching and learning process is the most suitable $(\bar{x}=4.85, S D=0.37)$.

Part 2: The results of the efficiency evaluation of DTL-Eco System divides into 4 aspects namely inputs, teaching processes with digital storytelling, outputs, and feedback. The aspect that has the highest evaluation is inputs $(\bar{X}=4.90$, $S D=0.30$ ) and from the evaluation of all 30 questions, the results of the evaluation of the use of digital tools in search and information processes have the highest assessment result $(\bar{x}=4.93, S D=0.28)$.

Part 3: The evaluation of the suitability of the DTL-Eco System divides into 3 major topics. The most appropriate result is the DTL-Eco System for the development of emotional intelligence in the digital world and the development of skills in using tools and digital media are possibly experiment $(\bar{X}=4.85, S D=0.38)$. In general, the evaluation results are at the level of most suitable $(\bar{X}=4.77$, $S D=0.43)$.

\section{CONFLICT OF INTEREST}

The authors declare no conflict of interest.

\section{AUTHOR CONTRIBUTIONS}

Kritsupath Sarnok Associate studied relevant research documents, analysed, conducted research experiments, summarized and wrote the paper. Panita Wannapiroon and Pachyanun Nilsook served as research advisors.

\section{ACKNOWLEDGMENT}

The researcher would like to thank the research support budget for the fiscal year 2019 from the National Research Agency (NRCT) and would like to thanks the Faculty of Education. Vongchavalitkul University, including King Mongkut's University of Technology North Bangkok.

\section{REFERENCES}

[1] Sarnok, "IoE links everything to smart classroom 4.0," presented at the National Academic Conference on Education $3^{\text {th }}$ "NACE 2017: Innovation of learning" Meeting, Lampang, Thailand, July 29, 2017.

[2] Sarnok and Wannapiroon, "Connectivism learning activity in ubiquitous learning environment by using IoE for digital native," Veridian e-Journal International (Humanities, Social Sciences and Arts), vol. 11, no. 4, pp. 405-418, January-June 2018.

[3] J. Reyna, "Digital teaching and learning ecosystem (DTLE): A theoretical approach for online learning environments," in Proc. Ascilite 2011 Hobart: Concise Paper, pp. 1080-1088, 2011.

[4] K. Sarnok, P. Wannapiroon, and P. Nilsook, "Digital learning ecosystem by using digital storytelling for teacher profession students," International Journal of Information and Education Technology (IJiET), vol. 9, no. 1 January 2019, pp. 21-26.

[5] I. K. Ficheman and R. De. Lopes, "Digital learning ecosystem: Authoring, collaboration, immersion and mobility," presented at Eighth IEEE International Conference on Advanced Learning Technologies, 2018.

[6] I. F. Silveira ${ }^{3}$ and Orther, "A digital ecosystem for the collaborative production of open textbooks: The LATIn methodology," Journal of Information Technology Education: Research, vol. 12, 2013, pp. 225-249.

[7] Wannapiroon, "Information technology and educational innovation," Faculty of Industrial Education, King Mongkut's University of Technology North Bangkok, 2016, pp. 159-161.

[8] J. S. Quaicoe, K. Pata, and E. Jeladze, "Digital learning ecosystem services and educational change in Ghana's basic schools," in EDULEARN16 Proceedings, $8^{\text {th }}$ Annual International Conference on Education and New Learning Technologies, 2016.

[9] M. Laanpere, K. Pata, P. Normak, and H. Põldoja, "Pedagogy-driven design of digital learning ecosystems," Computer Science and Information Systems, vol. 11, no. 1, pp. 419-442, 2013.

[10] M. Carrier and H. Learning, "Digital learning trends 2017-2020," QLS, 2017, Thessalonica, pp. 1-61, 2017.

[11] A. Davis, "Co-authoring identity: Digital storytelling in an urban middle school," Then Journal, 2018.

[12] D. B. Kent, "Digital storytelling implementation in an ECASA program Woosong University," Stem, vol. 12, no. 1, 2011.

[13] J. Lambert, Digital Storytelling: Capturing Lives, Creating Community, Berkeley, CA: Digital Diner Press.

[14] N. Jeerungsuwan, "Instructional design and assessment," Faculty of Industrial Education, King Mongkut's University of Technology North Bangkok, 2016, pp. 1-278.

[15] K. Sarnok, P. Wannapiroon, P. Nilsook, and N. Chalermsuk, "System architecture and elements of digital learning ecosystem for teaching and learning with digital storytelling for teacher profession students," SIKKHA Journal of Education, vol. 6, no. 2, July-December 2019, pp. 103-116.

[16] K. Sarnok, P. Wannapiroon, and P. Nilsook, "Digital learning ecosystem by using digital storytelling to develop pre-service teachers' digital intelligence," presented at the Opened Colloquium: King Mongkut's University of Technology North Bangkok, 2019.

[17] E. Jeladze and K. Pata, "Smart, digitally enhanced learning ecosystems: Bottlenecks to sustainability in Georgia," Sustainability, 2018, pp. $1-19$.

[18] J. S. Quaicoe, K. Pata, and E. Jeladze, "Digital learning ecosystem services and educational change in Ghana's basic schools," in EDULEARN16 Proc. Conference: 8th International Conference on Education and New Learning Technologies, 2016.

[19] M. Laanpere, K. Pata, P. Normak, and H. Põldoja, "Pedagogy-daiven design of digital learning ecosystems," Computer Science and Information Systems, vol. 11, no. 1, pp. 419-442.

[20] J. Lambert, "Digital storytelling COOKBOOK," Center for Digital Storytelling, January, 2010, pp. 1-40.

[21] K. Vänni, "Storytelling Seven steps," TAMK/Paja, October, 25, 2017, pp. 1-24. 
[22] H. A. Alismail, "Integrate digital storytelling in education," Journal of Education and Practice, vol. 6, no. 9, 2015, pp. 126-130.

[23] C. A. Nagaoka and K. Santawee, "The factors influencing information and digital media literacy of youth in Bangkok," The Journal of Social Communication Innovation, vol. 7, no. 13, Jan 2019, pp. 55-62.

[24] B. Robin and M. Pierson, "A multilevel approach to using digital storytelling in the classroom," in Proc. Society for Information Technology and Teacher Education International Conference 2005, pp. 655-662, Chesapeake, VA: AACE, 2005.

[25] N. Phumeechanya et al., "Ubiquitous scaffolding learning management system," in Proc. National Conference on Educational Technology 2015: NCET 2015, Jan 2015, pp. 22-33.

[26] A. Tendero, "Facing versions of the self: The effects of digital storytelling on English education," Contemporary Issues in Technology and Teacher Education, vol. 6, no. 2, 2006.

Copyright $\odot 2020$ by the authors. This is an open access article distributed under the Creative Commons Attribution License which permits unrestricted use, distribution, and reproduction in any medium, provided the original work is properly cited (CC BY 4.0).

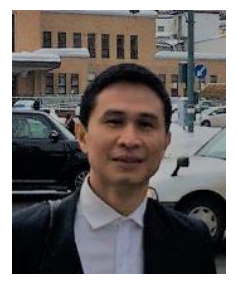

Kritsupath Sarnok is a lecturer of Technology and Computer Program, Faculty of Education, Vongchavalitkul University, Thailand.

$\mathrm{He}$ is an experience and expert in the field of educational technology, information technology for learning and teaching, and research in educational technology and innovation.

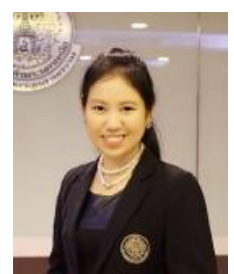

Panita Wannapiroon is an associate professor in the Division of Information and Communication Technology for Education, The Faculty of Technical Education at King Mongkut's University of Technology North Bangkok (KMUTNB), Bangkok, Thailand. She has experience in many positions such as the director at Innovation and Technology Management Research Center, assistant director of Online Learning Research Center, Assistant Director of Vocational Education Technology Research Center, and Assistant Director of Information and Communication Technology in Education Research Center. She also received The Burapha University Thesis Award 2002. And she is a Membership of Professional Societies in Association for Educational Technology of Thailand (AETT).

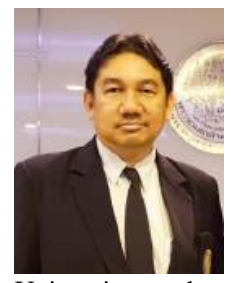

Prachyanun Nilsook is an associate professor at Division of Information and Communication Technology for Education, Faculty of Technical Education, King Mongkut's University of Technology North Bangkok (KMUTNB), Thailand. He received the B.Ed. in audio-visual education, from Faculty of Education, Ramkhamhang University. He obtained his M.Ed. in educational technology from, Srinakarinwirot University, and received the Ph.D. in educational communications and technology from Chulalongkorn University. From 2001 to present, he works in the field of information and communication technology in education. He has experience in many positions such as the dean, the faculty of technical education, Samutsongkhram Technical Collage and the Head of Vocational Education Technology Research Center. He received National Teachers Award of the Year in Higher Education 2004 from National Teacher Council, Ministry of Education, and Thailand. He is a membership of Professional Societies in Association for Educational Communication and Technology of Thailand (AECTT). 